\title{
HISTÓRIA E LITERATURA: FONTES LITERÁRIAS NA PRODUÇÃO HISTORIOGRÁFICA RECENTE NO BRASIL
}

\author{
History and Literature: Literary sources in the recent \\ historiographic production in Brazil \\ Virgínia Camilotti* \\ Márcia Regina C. Naxara**
}

\begin{abstract}
RESUMO
Pode-se constatar que a utilização da literatura como material de inquirição, que pareceu ilegítima ou desqualificada aos historiadores de ofício durante grande parte do século XX, disseminou-se como prática a partir dos anos 1970, quando ocorreram movimentos de aproximação que, a nosso ver, indicam modos diferenciados de operação com o texto literário. Modos que, por sua vez, são decorrentes de formas também distintas de conceber e lidar com as noções de autor, discurso, (con)texto e, sobretudo, com o literário e o político. Procurando compreender afastamentos e aproximações e consultando parte das pesquisas que, no Brasil, têm a literatura como fonte, consideramos neste ensaio a possibilidade de explorar pelo menos dois modos contrapostos: um, em que o literário é tomado como substrato de inquirição pelo historiador, tendo em vista a reconstituição do que é identificado pelo nome de História, como algo que o antecede em existência; outro, em que é tomado como substrato para o escrutínio de percepções, representações, figurações, por meio das quais se buscam os movimentos de instituição de imaginários e da própria temporalidade enquanto tal. Nesta aproximação do tema, pretendemos detectar alguns dos elementos que compõem essas diferentes formas, sem a intenção de rotular e determinar filiações.
\end{abstract}

Palavras-chave: história; literatura; fontes literárias.

* Bacharel e licenciada em História pela Universidade Estadual de Campinas. Mestre em História Social do Trabalho e Doutora em História pela mesma Universidade. Professora do Curso de História da Universidade Metodista de Piracicaba.

** Professora Assistente Doutora junto ao Departamento de História da FHDSS - UNESPFranca. Integra o Núcleo História e Linguagens Políticas: razão, sentimentos e sensibilidades - Grupo de Pesquisa Cadastrado no CNPq. 


\begin{abstract}
The use of literature as research material, which was considered illegitimate or disqualified by historians for most of the $20^{\text {th }}$ century, has been a widespread practice since the 1970s, when approximation movements took place, pointing, in our point of view, to different ways of working with the literary text. In turn, these ways originate from distinct forms of understanding and dealing with the concepts of authorship, discourse, (con)text, and, above all, literature and politics. In an attempt to understand divergences and convergences, and consulting part of the research in Brazil which have literature as source, in this essay, we consider the possibility of exploring at least two counterpoised perspectives: one, in which the literary is taken as a substratum of inquiry by the historian, considering the reconstitution of what is identified as History as something that antecedes in existence; the other, in which it is taken as a substratum for the scrutiny of perceptions, representations, figurations, by means of which we investigate how the imaginary and the temporal are instituted as such. In this approach to the theme, we attempted to detect some elements that compose these different perspectives with no intention of establishing labels or determining filiations.
\end{abstract}

Key-words: history; literature; literary sources.

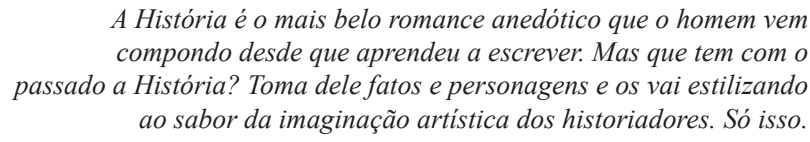

Monteiro Lobato ${ }^{1}$

\footnotetext{
1 Romance de 1926, escrito para o rodapé de A Manhã. O excerto remete para diálogo desenvolvido por dois personagens de $O$ presidente negro: o cientista Professor Benson, que havia inventado formas de alcançar o conhecimento do passado e do futuro, e Ayrton, homem comum que, ao acaso, entrou em contato com o primeiro. A fala é do homem de ciência. Citamos a sequência: "[Airton] — E os documentos da época? Insisti. // [Benson] — Estilização parcial feita pelos interessados, apenas. Do presente, meu caro, e do passado, só podemos ter vagas sensações. Há uma obra de Stendhal, $L a$ Chartreuse de Parme, cujo primeiro capítulo é deveras interessante. Trata da batalha de Waterloo, vista por um soldado que nela tomou parte. O pobre homem andou pelos campos aos trambolhões, sem ver o que fazia nem compreender coisa nenhuma, arrastado às cegas pelo instinto de conservação. Só mais tarde veio a saber que tomara parte na batalha que recebeu o nome de Waterloo e que os historiógrafos pintam de maneira tão sugestiva. Os pobres seres que inconscientemente nela funcionaram como atores, confinados a um campo visual muito restrito, nada viram, nem nada podiam prever da tela heroica que os cenógrafos de história iriam compor sobre o tema. Eis o presente...”. LOBATO, Monteiro. O presidente negro ou O choque das raças (romance americano do ano 2228). In: A onda verde e O presidente negro. 4. ed. São Paulo: Brasiliense, 1951.p. 123-330; citação p. 167.
} 
A história é o produto mais perigoso que a química do intelecto elaborou. Suas propriedades são bem conhecidas. Ela faz sonhar, embriaga os povos, provoca falsas lembranças, exagera seus reflexos, cultiva suas velhas feridas, atormenta-os quando em repouso, os conduz ao delírio de grandeza ou ao de perseguição, e torna as nações amargas, soberbas, insuportáveis e vãs. A história justifica aquilo que quisermos. Ela não ensina rigorosamente nada, pois contém tudo e fornece exemplos de tudo.

Paul Valéry ${ }^{2}$

Há questões incontornáveis quando se trata de refletir sobre as relações entre história e literatura na modernidade, tendo em vista a fluidez das fronteiras que, mais do que separá-las, as aproxima. Ambas abordam temas comuns sob diferentes perspectivas, utilizam formas aproximadas para se concretizarem - a escrita em suas variadas dimensões. Trata-se, aqui, de considerar a instabilidade das fronteiras entre história e literatura na especificidade da utilização de fontes literárias pelos historiadores na produção historiográfica realizada recentemente no Brasil (em torno dos últimos 30 anos). Não se trata de inventário sistemático, mas da procura do indiciamento dos diferentes modos com que os historiadores vêm operando com o literário, na tentativa de recuperar a historicidade da constituição de seus afastamentos e aproximações, tendo em vista colaborar para as reflexões sobre as diferentes possibilidades que os textos portadores de literariedade oferecem ao historiador. Um primeiro esboço, portanto.

I

Iniciamos por algumas reflexões a propósito do afastamento entre a história e a literatura no século XIX, comum a grande parte dos estudos que procuram recuperar a constituição da história como disciplina em suas especificidades e particularidades. Neste sentido, partimos da consideração de que se possa aventar que o processo de autonomização da arte que

2 VALÉRY, Paul. De l'histoire. In: Regards sur le monde actuel et autres essais. Paris: Gallimard, 1945. p. 39. Tradução de Jacy Seixas. 
percorre todo o século XIX, compreendendo seu afastamento do referencial até um esteticismo radical, tal como preconizado nas preleções de August Schlegel sobre a literatura ${ }^{3}$, constituiu (ao menos aparentemente) forte razão para o predomínio, durante grande parte do século XX, de um radical apartamento ou desqualificação da literatura como material de inquirição para a constituição de suas narrativas, pelos historiadores de ofício; ou, também, em forte razão para a afirmação da ilegitimidade da história de se ocupar do significado de expressões literárias, obras e autores num determinado tempo. Neste último caso, ainda, pode-se considerar o abalo sofrido pela figura canônica do autor até a radicalidade da decretação de sua própria morte pela moderna literatura de final do século XIX e primeiras décadas do século $\mathrm{XX}^{4}$.

Ao tributarmos a razão deste apartamento ou de uma aproximação impensada entre história e literatura durante grande parte do século XX aos movimentos da própria arte, não o fazemos fortuitamente. É certo que parece existir, num primeiro momento, nesta inversão de hipótese explicativa, uma idiossincrasia própria ao ofício - historiadores são (ou deveriam ser), por excelência, sujeitos desconfiados. Para nós, a glosa constantemente reiterada de que a história no século XIX, durante seu processo de institucionalização ou disciplinarização era, sobretudo, política, naturalmente política ou relacionada aos eventos políticos, como se desde sempre tivesse sido esta a sua vocação, é uma dessas assertivas que merece senão questionamento, pelo menos algum nível de dissipação.

Se pudermos colocar em suspensão, ainda que por alguns instantes, duas assertivas indiscutíveis a propósito da história no seu processo de disciplinarização: uma referente às relações desta com o literário entendido

3 A propósito ver a apresentação de Ruth Röhl à tradução de fragmentos sobre a modernidade na literatura alemã. Apresentação. In: CHIAMPI, Irlemar. (Coord.) Fundadores da modernidade. São Paulo: Ática, 1991. p. 21-25.

4 BARTHES, Roland. A morte do autor (1968). In: O rumor da lingua (1984). Trad. Mario Laranjeira. São Paulo: Brasiliense, 1988. p. 65-70. Citamos: "Mallarmé [...] viu e previu em toda a sua amplitude a necessidade de colocar a própria língua no lugar daquele que dela era até então considerado proprietário; para ele, como para nós, é a linguagem que fala, não o autor; [...]. Valéry [...] reivindicou ao longo de todos os seus livros em prosa a favor da condição essencialmente verbal da literatura, face à qual todo recurso à interioridade do escritor lhe parecia pura superstição." Indicamos ainda que do surrealismo Barthes destaca a afirmação do princípio de uma escritura coletiva; e da linguística o argumento de que "a enunciação em seu todo é um processo vazio que funciona perfeitamente sem que seja necessário preenchêlo com a pessoa dos interlocutores" (p. 66-67). 
como parcela de literariedade cabível à sua escrita; e outra relativa ao seu próprio objeto - o político -, talvez seja possível dimensionar a fertilidade da hipótese que levantamos.

Para a primeira recuperemos Hayden White descrevendo o horizonte discriminativo que se figurava ao historiador do último quartel do século XIX, quando se tratava de fazer referência ao exercício de seu ofício: “o historiador devia tentar ser 'científico' em sua investigação dos documentos e em seus esforços por determinar 'o que de fato aconteceu' no passado, e [...] representar o passado 'artisticamente' para seus leitores" ${ }^{5}$. Para a segunda recuperemos Peter Burke no trecho em que procura esclarecer a divisão de trabalho estabelecida entre o romancista histórico clássico do século XIX e o historiador de ofício, dando como certos e estabelecidos os materiais e produtos dos quais a história se ocupava:

a fronteira entre história e ficção foi relativamente nítida durante esse período. [...] Historiadores profissionais, na era de Ranke e seus discípulos, se restringiram a narrativas de grandes eventos e aos feitos de grandes homens. Por sua vez, os romancistas históricos clássicos não interferiram em interpretações correntes da história, e menos ainda em grandes eventos; ao contrário, aceitaram-nos como verdadeiros. Romancistas tinham licença para inventar personagens menores, ilustrando os efeitos de grandes mudanças históricas num nível local ou pessoal ${ }^{6}$.

Em contraposição a estas duas assertivas, e, em favor do que procuramos afirmar, uma rápida exploração de Jules Michelet, por exem-

5 WHITE, Hayden. Meta-história: a imaginação histórica do século XX (1973). Trad. José Laurênio de Melo. São Paulo: Edusp, 1992, p. 148.

6 BURKE, Peter. As fronteiras instáveis entre História e Ficção. In: AGUIAR, Flávio; MEIHY, José Carlos Sebe Bom; VASCONCELOS, Sandra Guardini T. (Orgs.). Gêneros de fronteira: cruzamentos entre o histórico e o literário. São Paulo: Xamã, 1997, p. 107-115; citação p. 112. Tais assertivas relativas à prática historiográfica e seus liames com a literatura no século XIX parecem ter como horizonte exclusivo, no traçado que definem para as relações entre os dois campos, apenas um dos veios que constitui a proveniência da disciplinarização da história, qual seja, aquele que remonta a Ranke e à escola histórica científica alemã e suas traduções na França, por meio de Ch.-V. Langlois, Ch. Seignobos e G. Monod. Veio esse direcionado desde seus começos à afirmação de que o historiador deveria recuperar os eventos, relativos ao âmbito do Estado, e suas tendências, através da documentação escrita e oficial de eventos políticos. Cf. BOURDÉ, Guy; MARTIN, Hervé. A escola metódica. In: As escolas históricas (1983). Portugal: Publicações EuropaAmérica, 1990, p. 97-118. 
plo, pode ajudar a perceber como o próprio fazer história, e aquilo que comportava ou podia comportar de literário, não se encontrava ao longo do século XIX apaziguado ou resolvido, como aparece na fórmula que White nos oferece. E, da mesma forma, nada tão claramente demarcado em termos de divisão de trabalho entre romancistas (em especial o romance histórico) e historiadores ou entre literatura e história e seus respectivos objetos de interesse, como quer fazer crer Burke.

Não esqueçamos que, tanto a história como a literatura, emergiram como campos disciplinares no sentido aqui utilizado, no limiar mesmo da modernidade. Como ruptura aos saberes anteriormente constituídos ${ }^{7} \mathrm{e}$, no caso da literatura, ruptura "em relação a um saber consolidado a partir de regras previstas nos tratados de retórica" e a partir de "uma inquietante pergunta sobre a sua instável e insustentável existência nos limites de um

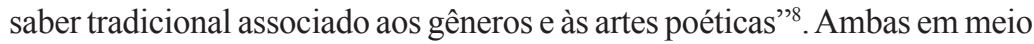
a tantas outras disciplinas que respondiam às ambições de conhecimento do mundo pelos homens, em momento que confere peso inédito para a historicidade dos acontecimentos naturais e humanos ${ }^{9}$, lembrando as diferentes vertentes do historicismo ${ }^{10}$.

História e literatura modernas que, desde o seu início compartilharam o interesse pelo humano - o homem, alçado à condição de objeto de conhecimento ${ }^{11}$. Compartilhamento enriquecedor e complexo, como procuraremos verificar, de forma bastante modesta, tomando em consideração O Povo [1846], de Michelet, e alguns de seus comentadores. A configuração de apartamento entre história e literatura - que se consolida nas últimas décadas do século XIX - tem também, uma, ou melhor, várias histórias.

7 FOUCAULT. Michel. As palavras e as coisas: uma arqueologia das ciências humanas (1966). Trad. Salma Tannus Muchail. 6. ed. São Paulo: Martins Fontes, 1992. p. 234-5.

8 ARAÚJO, Joana L. Muylaert de. A literatura como simulacro: uma questão ainda sensível? In: SEIXAS, Jacy; CERASOLI, Josianne. UFU, ano 30 - tropeçando universos (artes, humanidades, ciências). Uberlândia: Edufu, 2008. p. 109-127; citação p. 9.

9 Cf. LEPENIES, Wolf. As três culturas (1985). Trad. Maria Clara Cescato. São Paulo: Edusp, 1996.

10 WEHLING, Arno. A invenção da história: estudos sobre historicismo. 2. ed. Rio de Janeiro: Ed.Gama Filho, 2001.

11 FOUCAULT. Michel. As palavras e as coisas (1966), 1992. Op. cit. Em especial Cap. X - As ciências humanas. 
Michelle Schreiner demonstra como $O$ Povo constitui elemento significativo para a compreensão dos jogos estabelecidos pelo historiador (que pensamos poder estender aos historiadores) para a reivindicação de um lugar para a história, e, em especial, a história como "literatura de formação de um povo" 12 . Tal reivindicação inscreve-se no compasso de um desencanto, frustração, e por fim, de rechaço a uma literatura identificada como romântica ${ }^{13}$, "da moda" ${ }^{14}$, que descrevia o povo como uma realidade defeituosa e degradante ${ }^{15}$.

Como razão para tal pintura do povo, compreendida enquanto retrato da constelação de valores, sentimentos, gestos e gostos dele constitutivos encontrava-se, aos olhos de Michelet, o próprio pintor, o homem da arte pela arte $^{16}$, o romântico, a acreditar que a arte estava, sobretudo, no feio e que "os efeitos artísticos mais infalíveis residiam no feio moral" 17 . Arte essa que, sabemos, se pretendia resposta da sensibilidade romântica à necessidade de evasão da vida moderna, do vazio desolador do real ${ }^{18}$; que, centrada na criatividade artística, postulava uma autonomia ou afastamento do referencial. E, aos olhos de Michelet, moralmente descompromissada, a esgotar-se num individualismo extremo.

É contra esta arte, sobretudo, que Michelet inscreve um lugar para a sua história. Mais do que não lhe servir de material ou manancial - por meio do qual pudesse perscrutar o povo nas suas características constitutivas e recolher traços de seu perfil - é mesmo em oposição a ela e almejando substituí-la que a história de Michelet se define. Justamente, ainda, a partir

12 SCHREINER, Michelle. Jules Michelet e a história que ressuscita e dá vida aos homens: uma leitura da emergência do "povo" no cenário historiográfico francês da primeira metade do século XIX. Tese (Doutorado) - IFCH-Unicamp, 2005. Em especial. p. 116 e 278.

13 A propósito desta questão ver também WILLIAMS, John R. Jules Michelet: historian as critic of french literature. Alabama: Summa Publications, 1987; VIALLANEIX, Paul. Prefácio. In: MICHELET, Jules. O povo (1846). Trad. Gilson César Cardoso de Souza. Prefácio e notas de Paul Viallaneix. São Paulo: Martins Fontes, 1988, p. VII-XLII; RANCIĖRE, Jacques. O relato fundador. In: Os nomes da história: um ensaio de poética do saber (1992). Trad. Eduardo Guimarães e Eni Puccinelli Orlandi. São Paulo: EDUC/ Pontes, 1994, p. 51-68; RANCIÈRE, Jacques. As palavras da história. In: Políticas da escrita. Trad. Raquel Ramalhete et al. Rio de Janeiro: Ed. 34, 1995, p. 205-226.

14 VIALLANEIX, Paul. Prefácio. 1988, Op. cit., p. XXVIII; SCHREINER, Michelle. Jules Michelet..., 2005. Op. cit., p. 104.

15 SCHREINER, Michelle. Jules Michelet... 2005. Op. cit., p. 23, 34 e 104.

16 MICHELET, Jules. O povo (1846). 1988. Op. cit., p. 119.

17 Ibid., p. 8.

18 A propósito, ver LÖWY, Michael; SAYRE, Robert. Revolta e melancolia. O romantismo na contramão da modernidade (1992). Trad. Guilherme João de Freitas Teixeira. Petrópolis: Vozes, 1995. 
do modo como o historiador procede na coleta de informações sobre o povo, observando a condição daquele que viu ou daquele que ouviu de quem viu, em franca recuperação da referência grega implicada no sentido dos termos historiè e histôr ${ }^{19}$. É, portanto, um Michelet romântico que rechaça a literatura romântica e reivindica para a história o papel de literatura de formação a partir da noção de testemunho. Coloca-se na posição de quem é capaz de, pelo testemunho e pela experiência, revelar ao próprio povo a constituição dos valores que lhe são particulares. Recorre, ainda, bem de acordo com as concepções românticas, a imagens fortemente marcadas pelo sentimento do sublime, que comportam grande força de persuasão e convencimento, tendo em vista sua carga e densidade imagética ${ }^{20}$.

François Hartog comenta que, depois de Heródoto, "o tempo da epopéia" havia "terminado", abrindo parênteses para afirmar que foi preciso aguardar "Michelet para reencontrar uma concepção épica da história", acentuando nele a concepção de um "historiador que pretende ser, ao mesmo tempo, 'vidente' e 'voyeur"', no sentido não propriamente de "preservar do esquecimento as ações valorosas, mas de transmitir às gerações futuras um instrumento de inteligibilidade de seu próprio presente"21.

Gesto ou corte claramente epistemológico e político, este que foi estabelecido por um dos mais importantes pilares da história ocidental Michelet. Gesto que não inscreve, em absolutamente nada, o político como prioridade exclusiva para o campo historiográfico no sentido dos grandes eventos e grandes homens, nos termos colocados por Burke. Pelo contrário, são formas, valores, costumes, sentimentos e práticas, e a figura do povo

19 Cf. GAGNEBIN, Jeanne-Marie. O início da história e as lágrimas de Tucídides. In: Sete aulas sobre linguagem, memória e história. Rio de Janeiro: Imago, 1997, p. 15-37, em especial p. 16. No Prefácio [O velho Heródoto] a $O$ espelho de Heródoto, François Hartog retoma e explicita o debate especializado sobre os sentidos, usos e vínculos dos dois termos. HARTOG, François. O espelho de Heródoto. Ensaio sobre a representação do outro (1980). Trad. Jacyntho Lins Brandão. Belo Horizonte: Ed. UFMG, 1999, em especial p. 21-22.

20 Para a temática podemos indicar, entre outros, BRESCIANI, Stella. O poder da imaginação: do foro íntimo aos costumes políticos. Germaine de Staël e as ficções literárias. In: SEIXAS, Jacy A.; BRESCIANI, Maria Stella; BREPOHL, Marion (Orgs.) Razão e paixão na política. Brasília: Ed. UnB, 2002, p. 31-46. NAXARA, Márcia R. C. Cientificismo e sensibilidade romântica: em busca de um sentido explicativo para o Brasil no século XIX. Brasília: Ed. UnB, 2004. Sobre o sentimento do sublime, em especial, BURKE, Edmund. Uma investigação filosófica sobre a origem de nossas idéias do sublime e do belo (1757). Trad., apresentação e notas de Enid Abreu Dobránszky. Campinas: Papirus; Ed. Unicamp, 1993; KANT, Emmanuel. Observações sobre o sentimento do belo e do sublime; Ensaio sobre as doenças mentais (1766). Trad. Vinicius de Figueiredo. Campinas: Papirus, 1993.

21 HARTOG, François. O espelho de Heródoto (1980). 1999. Op. cit., p. 28 
como entificação da própria história que interessam à escrita de Michelet. No que diz respeito ao procedimento que assegura a apreensão de uma anatomia em vez da aparência, tem-se a experiência com o povo de quem dele saiu (experimenta-o de dentro) ${ }^{22}$, de quem o ouviu tanto quanto aos documentos, contrariamente aos romancistas como George Sand, Eugène Sue e Honoré de Balzac que, considerava Michelet, captavam apenas o superficial, o pitoresco e o dramático ${ }^{23}$.

No entanto, a despeito desta ênfase na particularização de procedimentos, conforme François Furet, Michelet lançava mão da adivinhação, da imaginação, sob o modo inverso da interpretação sociológica ${ }^{24}$, para talhar, por exemplo, a imagem da Revolução Francesa. Sua operação de ouvir os documentos, na afirmação de Jacques Rancière, não o fazia leitor que buscasse "revelar, [...] trazer à superfície o conteúdo da documentação, o que, mais tarde, os historiadores positivistas chamariam de 'deixar o documento falar por si mesmo" "25; mas, de outro modo, deles falando, "não as suas palavras, mas sua materialidade, sua cor, seus ornamentos", Michelet descrevia mais os seus próprios sentimentos ao tomar conhecimento de seu conteúdo ${ }^{26}$.

Nesse sentido, o rechaço de Michelet à literatura era menos por seus vínculos com a imaginação e com a busca de efeitos que mobilizassem a sensibilidade, e mais para com os procedimentos próprios à literatura que nomeava de romântica, a esgotar-se num artifício extremo em busca do efeito artístico e, por conta disto, daquilo que retratava e como retratava.

Se o corte com a literatura, em Michelet, se efetua em função do conteúdo que se desdobra de uma arte descompromissada com a formação do povo - que não se vale de sua capacidade de tocar a sensibilidade e promover

22 SCHREINER, Michelle. Jules Michelet... 2005. Op. cit., p. 178.

23 Vale destacar que a investida de Michelet contra o que considerava a literatura romântica se estabelece sobre os romances Indiana e Lélia (George Sand), Les mystères de Paris (Eugène Sue) e Les paysans (Honoré de Balzac). Cf. VIALLANEIX, Paul. Prefácio. 1988, Op. cit., p. XXVIII.

24 FURET, François. Pensando a revolução francesa. Apud SCHREINER, Michelle. Jules Michelet... 2005. Op. cit., p. 252. A passagem exata de Furet é: "Na mesma época em que Michelet concebeu a mais penetrante das histórias da Revolução já escritas sob o modo da identidade - uma história sem conceitos, feita de achados do coração, marcada por uma espécie de adivinhação das almas e dos atores - Tocqueville imagina, e ele foi o único a tê-la imaginado assim, a mesma história, sob o modo inverso da interpretação sociológica."

25 RANCIËRE, Jacques. Les mots de l'histoire. Apud SCHREINER, Michelle. Jules Michelet... 2005. Op. cit., p. 21, nota 39.

26 SCHREINER, Michelle. Jules Michelet... 2005. Op. cit., p. 21, nota 39. 
a coesão, mas é exclusivamente expressão prisioneira de um individualismo extremo - pode-se também vê-lo como processo de apartamento da história de uma arte que não teria o que dizer sobre os traços constitutivos do povo, ou do que a história definisse como foco. Poder-se-ia indagar se já não se inscrevia então um terreno bastante propício à emergência da futura ciência do literário, ciência autônoma, capaz de lidar com um objeto autossuficiente - a teoria literária ${ }^{27}$.

A questão torna-se mais complexa ainda, se tomamos em consideração as aproximações entre Michelet e Balzac apontadas por Carlo Ginzburg. A partir da leitura de Eric Auerbach, Ginzburg aproxima os dois escritores ao historicismo, assinalando em Balzac uma convergência entre "romancista e historiador". Nas palavras de Auerbach: "Historicismo atmosférico e realismo atmosférico estão intimamente ligados; Michelet e Balzac são levados por idênticas correntes [...]. Tal concepção e tal prática [as de Balzac] são totalmente historicistas" ${ }^{\prime 28}$. Por outro lado, para o autor de Mimesis, Stendhal não seria "plenamente moderno" pois "a mentalidade com que [...] olha para os acontecimentos e o modo como procura reproduzilos em suas conexões é muito pouco influenciada pelo historicismo [Historismus]", uma vez que estaria mais próximo de uma "analyse $d u$ coeur humain' completamente enformada pela psicologia moralista clássica, e não pela investigação ou a intuição de forças históricas. Nele se encontram motivos racionais, empíricos, sensualistas, mas dificilmente motivos romântico-historicistas"29.

27 "Os estudos literários convertem-se em Teoria da Literatura quando se solidifica a noção de que se torna imprescindível a existência de uma ciência autônoma, capaz de lidar com um objeto autossuficiente - a obra de arte literária. O formalismo russo foi uma das expressões mais consistentes desse princípio, e não por coincidência ele é contemporâneo e parceiro do modernismo, em especial do futurismo, vertente de vanguarda que se destacou sobretudo nas primeiras décadas no século XX, seja na Europa, seja na América, haja vista a adesão a ele por Oswald de Andrade, entre nós, no início dos anos 20." Fontes - porque primárias. In: ZILBERMAN, R.; MOREIRA, M. E.; BORDINI, M. da G.; REMÉDIOS, M. L. R. (Orgs.). As pedras e o arco: fontes primárias, teoria e história da literatura. Belo Horizonte: Ed. UFMG, 2004, p.13-16; citação p. 14.

28 GINZBURG, Carlo. A áspera verdade - Um desafio de Stendhal aos historiadores. In: $O$ fio e os rastros (2006). Trad. Rosa Freire d'Aguiar e Eduardo Brandão. São Paulo: Companhia das Letras, 2007, p. 170-188. Citações p. 172-173. Importante assinalar o propósito do autor em distinguir Historismus e Historicismo. Citamos: "Nesta altura, poderíamos ficar tentados a identificar o ponto de vista de Auerbach com o Historismus alemão - uma categoria que não deve ser confundida nem com o historicismo italiano, nem com o New Historicism americano".

29 AUERBACH, Eric. Mimesis. Apud GINZBURG, Carlo. A áspera verdade (2006). 2007. Op. cit., p. 172. 
$\mathrm{O}$ argumento permite, nos parece, uma aproximação de Michelet e Balzac às premissas historicistas, que remetem para concepções de mundo românticas, nem sempre identificadas ao que se convencionou chamar romance romântico de que Michelet tanto procurara se distanciar.

Se essa hipótese explicativa sobre o distanciamento entre história e literatura pode suscitar polêmica, parece não haver discordâncias quanto a se considerar que, a partir dos anos 1970 e, em especial, no que se refere à historiografia praticada no Brasil, dos anos 1980, houve um significativo deslocamento ou alteração deste quadro. Deslocamento que se insere no amplo movimento de renovação das práticas historiográficas que buscaram em Michelet e em outros autores do século XIX uma demarcação de ancestralidade e filiação ${ }^{30}$. Costumes, valores compartilhados, manifestações culturais, vínculos identitários... passaram a ser foco de interesse de historiadores, em abordagens tributárias da nova história e da história social.

Da mesma forma, talvez também não suscite polêmica afirmar o caráter paradoxal de que se revestem as aproximações entre os dois campos a partir deste período. De um lado, pode-se notar a negação peremptória dos historiadores de ofício desta aproximação, quando a exemplo de Hayden White ${ }^{31}$, ela tem como ponto de partida a literatura enquanto conhecimento do literário (teoria literária), na sua pretensão de desvelar o quanto a forma, ou a dotação de sentido efetuada para uma narrativa histórica, define, ou melhor, inscreve o conteúdo narrado; ou mesmo o descaso, quando Dominick Lacapra, também à guisa de exemplo, sugere que as experiências estéticas do início do século XX, ou os modos como a literatura modernista figurou as múltiplas temporalidades implicadas nas experiências vividas, fossem tomadas como recurso de inspiração para urdidura de enredos que rompessem com a forma tradicional da história contar/narrar calcada no romance clássico do século $\mathrm{XIX}^{32}$. E, de outro lado, uma crescente e afirmativa aproximação entre os dois campos, quando

30 LE GOFF, Jacques. (1978) (Dir.). A história nova. Trad. Eduardo Brandão. São Paulo: Martins Fontes, 1990. p. 25-64.

31 WHITE, Hayden. O texto histórico como artefato literário. In: Trópicos do discurso: Ensaios sobre a crítica da cultura (1978). Trad. Alípio Correia de França Neto. São Paulo: Edusp, 1994, p. $97-116$.

32 LACAPRA, Dominick. História e Romance (1985). Trad. Nelson Schapochnik. Revista de História, IFCH-Unicamp, n. 2-3, p. 107-124, 1991. 
o movimento define um vetor que tem como ponto de origem a história em direção ao literário.

É instigante notar como, nos anos 1990, são expostas as razões para a aproximação entre os campos que têm como ponto de partida a história, em termos bastante naturais, na voz de um crítico de literatura:

O historiador, sobretudo o historiador do mundo colonial, está movido por um desejo de totalização que eu acho [...] muito propício para o mundo em que vivemos hoje; isto é, o desejo de enriquecer e aprofundar os seus conteúdos. De alguma maneira, ele considera, senão esgotados [...], já desenvolvidos até um limite extremo o discurso economicista, ou o discurso que fala só sobre a cultura material, ou o discurso dos fatos políticos mais berrantes. [...] O historiador moderno, particularmente o historiador das colônias [...] desejaria ir mais fundo, isto é, estudar e conhecer as motivações internas, a sensibilidade; tudo quanto faz com que o ser humano seja essa coisa plástica, imprevisível, que a historiografia sociológica e a historiografia economicista reduziram a certos parâmetros. [...] Este momento é meio embriagador; [...] embriagador no sentido de se tentar o enriquecimento dos conteúdos, o aprofundamento até o nível da sensibilidade, aquele nível que é tratado normalmente pela psicologia, pela psicanálise, pela antropologia. Esse nível é também o nível ficcional [...] se ele quer comprovar que realmente no século XVII havia tais e tais tendências no campo da afetividade, ele vai à literatura e tira dela os testemunhos que lhe interessam, para compor uma história complexa, rica, que abrace o externo, mas também o interno ${ }^{33}$.

Esgotamento das explicações históricas até então atuantes nas narrativas, necessidade de ampliação, adensamento, complementação, expansão que leva ao escrutínio de dimensões outras do ser humano, no caso o sensível ou o interno, matéria da qual a literatura é boa servidora, eis os elementos destacados por Alfredo Bosi no seu diagnóstico para o caso da aproximação da história em direção ao literário. Formulação bastante

33 BOSI, Alfredo. Debatedores: Alfredo Bosi e José Carlos Sebe Bom Meihy. In: CHIAPPINI, Ligia; AGUIAR, Flávio Wolf de (Orgs.). Literatura e história na América Latina - seminário internacional, 9 a 13 de setembro de 1991. São Paulo: Edusp, 1993, p. 135-141; citação p. 138-139. 
aceitável, diga-se de passagem, à própria teoria literária, uma vez que mantém intocada certa divisão de trabalho até então fixada para os dois campos. Eis porque, talvez, o tom do crítico é mesmo de saudação para as novas escolhas dos historiadores. Ele até nos sugestiona a pensar que o que se assiste é a reedição de um movimento que teria seu modelo em Michelet, ou, ao menos, na reposição da expectativa - frustrada no caso de Michelet - de que a literatura servisse à história pela sua condição de repositório de gestos, gostos, afetos, sentimentos, para a confecção de um perfil ou de perfis.

Todavia, o movimento em direção ao literário, que na pena de Bosi ganha uma motivação e formato único, já se revelava nos princípios dos anos 1990 bem mais complexo e matizado, para não dizer mais ambicioso, amplo, com traços que implicavam, inclusive/talvez, uma dissipação da divisão de trabalho entre os dois campos, ela própria reafirmada pelo esboço de Bosi.

Como primeiro complicador para o caso, podemos destacar que os historiadores já estavam e estão nesse processo de aproximação do literário (autoconfiantes de um aparelho crítico particular ao campo), interessados em averiguar e mesmo em refletir sobre imagens erigidas para autores e obras pela teoria literária, ou talvez sobre sua condição de ficções de verdades historicamente constituídas. O que, em outras palavras, significa muito mais que uma apropriação do literário na sua condição de reservatório do sensível para o recolhimento de materiais que beneficiem a constituição de narrativas ocupadas com o humano, essa "coisa plástica e imprevisível", nos termos de Bosi. Significa mesmo um movimento que rivaliza com uma ciência autônoma, que se funda justamente na admissão de um objeto autossuficiente.

A complexidade não se esgota, pois as aproximações do literário, que têm como ponto de partida a história, revestem-se de distinções. Distinções que se inscrevem num quadro polêmico, cujos movimentos, na maior parte das vezes, velados, não ditos, são, porém, atuantes. Trata-se, em linhas gerais, de diferentes modos de operação com o literário que se distanciam em razão daquilo que pressupõem e instituem para as noções de autor, história, (con)texto, e, sobretudo, o literário e o político, e, mais especialmente, para as relações entre estes dois últimos.

Centrando suas reflexões na ideia da história como "invenção", Durval Muniz de Albuquerque Jr. verificou o quanto o termo invenção, 
conquanto seja utilizado por muitos historiadores - para o mesmo período que analisamos - não se dá por meio do consenso, mas pela existência de

duas posturas epistemológicas distintas, uma que chamaria atenção para o papel do discurso, da narrativa, no processo de invenção dos objetos históricos, uma outra que toma o objeto como algo que preexiste ao discurso, como algo que, estando oculto, seria revelado ou espelhado pelo discurso do historiador $^{34}$.

Separação "entre a coisa em si e a construção social do conhecimento" que - continua Albuquerque Jr. - para Bruno Latour e Michel Foucault seriam "produtos da sociedade moderna e um dos seus pressupostos fundamentais" 35 .

Retomando o campo específico das relações história e literatura, no quadro polêmico já anunciado, podemos visualizar pelo menos dois modos de operação bastante diferenciados/contrapostos e, entre os mesmos, uma grande variabilidade de formas intermediárias, que demonstram a importância dos textos literários para a história e que decorrem, também, do aumento da pesquisa e da constituição de novos locais para o seu desenvolvimento. No limite, dois veios de investigação que, por vezes, são evocados como um campo específico da escrita da história - uma historiografia do literário ou a partir do literário no Brasil.

Dessa forma, num extremo, o literário é tomado como substrato de inquirição pelo historiador, tendo em vista a reconstituição do que é identificado pelo nome de História, como algo que o antecede; no outro, o literário é tomado como substrato para o escrutínio de percepções, representações, figurações, por meio das quais se busca os movimentos de instituição de imaginários e da própria temporalidade enquanto tal.

Numa analogia audaciosa, procuramos seguir o ensinamento de Auerbach, no Epílogo a Mimesis, na afirmação de que em "pesquisas desta espécie, não se mexe com leis, mas com tendências e correntes que se

34 ALBUQUERQUE JR., Durval Muniz de. Introdução. Da terceira margem eu so(u)rrio: sobre história e invenção. In: História: a arte de inventar o passado. Bauru-SP: Edusc, 2007, p. 19-39; citação p. 21-22.

35 Ibid., p. 22. 
entrecruzam e complementam da forma mais variada possível"36, colocandose a necessidade de acomodamento da multiplicidade e elasticidade das formulações que vão sendo encontradas. Assim, detectar elementos importantes que constituem essas diferentes formas de operação com o literário, procurando indicar algumas possíveis nuances, sem a intenção de rotular e determinar filiações, linhagens e lugares específicos possibilitará, talvez, indiciar ditos e não ditos das polêmicas que se inscrevem no movimento de aproximação da história para a literatura.

Dentre os importantes veios de investigação que se inscrevem no primeiro dos modos de operação com o literário mencionado (podemos dizer que num de seus extremos) - que toma o literário enquanto substrato de inquirição para a reconstituição da História -, encontra-se aquele que apresenta um gesto claro de autodesignação: história social da literatura, epíteto utilizado em grande parte das suas publicações ${ }^{37}$.

O escrutínio do literário, neste caso, efetua-se sobre dois polos relacionados às imagens mesmas daquilo que constituem o objeto e o sujeito de conhecimento. Para o primeiro caso, a obra literária é tomada como algo que necessariamente remete ao sujeito que a assina, sendo captável em sua intencionalidade, de que resulta a figura do historiador enquanto decifrador, como sujeito ativo do processo de apreensão. $\mathrm{O}$ uso que fazemos aqui do termo "decifrador" para a figura do sujeito de conhecimento que se projeta dos trabalhos deste veio investigativo é tributário das formulações de Barthes em "A morte do autor". Para tal sujeito de conhecimento está facultado o encontro do enigmático e secreto significado último de um texto, que tem na figura do autor, ou, conforme Barthes, na sociedade, história ou psique,

36 AUERBACH, Eric. Mimesis. A representação da realidade no mundo ocidental (1946). 2. ed. revisada. São Paulo: Perspectiva, 1987. p. 501-502.

37 Cf. especialmente CHALHOUB, Sidney; PEREIRA, Leonardo A. de Miranda. (Orgs.) A história contada: capítulos de história social da literatura no Brasil. Rio de Janeiro: Nova Fronteira, 1998; CHALHOUB, Sidney; NEVES, Margarida de Souza; PEREIRA, Leonardo A. de Miranda (Orgs.). História em cousas miúdas: capítulos de história social da crônica no Brasil. Campinas-SP: Ed. Unicamp, 2005. 
hipóteses dele explicativas, a sua morada ${ }^{38}$. Na sua condição de decifrador de uma intencionalidade que se destina invariavelmente ao mundo, a um mundo que cerca e precede a obra, esse sujeito de conhecimento se designa mais precisamente como "profanador":

[...] a principal característica desta coletânea é mesmo a disposição de se apropriar da literatura com a maior semcerimônia - despudoradamente, se nos permitem dizer assim. Diante dos poetas e prosadores do Olimpo das letras não passamos com chapéu à mão, curvando-nos respeitosamente. Chapéu à banda, passamos gingando. Por obrigação de ofício historiadores sociais são profanadores ${ }^{39}$.

"Profanador" já que funda seu empreendimento na descrença da "transcendência" ou da "autonomia da literatura", asseguradas em última instância pela "atividade de 'criadores singulares', atemporais, cujas obras seriam validadas por critérios estéticos absolutos" ${ }^{\text {"40 }}$. Intrigante associação de referências a sustentar a reivindicação do direito/ou autoridade para falar do literário. Como se a noção de gênio, ou a concepção de uma arte, cuja vontade criativa reside na individualidade ou no ego, justificasse a existência de uma ciência exclusiva do literário, e não exatamente o contrário. A contestação de critérios estéticos absolutos, a dissipação da noção de gênio, como condição daquele que se abandona aos impulsos de sua imaginação, inspiração e criatividade ${ }^{41}$, e a dissolução da noção de "eu" 42 como origem e causa da vontade criativa constituem-se eventos ou momentos que esclarecem a proveniência de uma ciência - a teoria literária - apropriada a um objeto que se proclama autônomo.

O sujeito de conhecimento desta história social da literatura, o "profanador", exercita o seu ofício como aquele que pretende resgatar e

38 Cf. BARTHES, Roland. A morte do autor (1968), 1988. Op. cit., p. 69.

39 CHALHOUB, Sidney; PEREIRA, Leonardo A. de Miranda. Apresentação. 1998. Op. cit., p.7.

40 Ibid., p.7.

41 A propósito da noção de gênio tal como compreendida pelo movimento Sturm und Drang e pelos românticos, ver VOLOBUEF, Karin. Frestas e arestas: a prosa de ficção do romantismo na Alemanha e no Brasil. São Paulo: Ed.Unesp, 1999, em especial, p.30.

42 Cf. a propósito desta questão: FRIEDRICH, Hugo. A estrutura da lírica moderna - da metade do século XIX a meados do século XX (1956). Trad. Ana Maria Ribeiro et al. São Paulo: Duas Cidades, 1991. 
religar o objeto ao mundo do qual ele se encontra apartado, mundo que recebe na pena destes historiadores o nome próprio de História. Mas que história? Algo que necessariamente antecede a obra, que guarda em relação a ela uma anterioridade inevitável, mundo do qual parte e ao qual se destina, mesmo que seus fins sejam intransitivos e seu exercício seja exclusivamente o do símbolo.

A propósito dos particulares modos de funcionamento de uma escritura/discurso que se inscreve como simbolização esclarece Barthes:

[...] desde que um fato é contado, para fins intransitivos, e não para agir diretamente sobre o real, isto é, finalmente, fora de qualquer função que não seja o exercício do símbolo, produz-se esse desligamento, a voz perde a sua origem, o autor entra na sua própria morte, a escritura começa $\mathrm{a}^{43}$.

Se o modo particular de funcionamento de uma escritura que se inscreve como simbolização é desconsiderado na operação efetuada sobre o literário pelos que se autodenominam profanadores, cabe ainda indicar que tal propósito parece se cumprir pressupondo uma indistinção entre atos de escrita e atos de fala. Tratar-se-ia talvez de uma outra ordem de

43 BARTHES, Roland (1968), 1988. Op. cit., p. 65. Ainda para clarear o problema da simbolização e o afastamento do referente aí implicado, vale a pena observar o que Edmund Wilson indica a propósito do simbolismo: "Os pressupostos em que se baseia o Simbolismo levam-nos a formular doutrina como a seguinte: Toda percepção ou sensação que tenhamos, a cada momento de consciência, é diferente de todas as outras; por conseguinte, torna-se impossível comunicar nossas sensações, conforme as experimentamos efetivamente, por meio da linguagem convencional e universal da literatura comum. Cada poeta tem uma personalidade única; cada um de seus momentos possui seu tom especial, sua combinação especial de elementos. E é tarefa do poeta descobrir, inventar, a linguagem especial que seja a única capaz de exprimir-lhe a personalidade e as percepções. Essa linguagem deve lançar mão de símbolos: o que é tão especial, tão fugidio e tão vago, não pode ser expresso por exposição ou descrição direta, mas somente através de uma sucessão de palavras, de imagens, que servirão para sugeri-lo ao leitor. Os próprios simbolistas, empolgados com a idéia de produzir, com a poesia, efeitos semelhantes aos da música, tendiam a considerar tais imagens como que dotadas de um valor abstrato, como o de notas e acordes musicais. Mas as palavras de nossa fala não são notação musical; na verdade, os símbolos do Simbolismo eram metáforas separadas de seu substrato, pois além de certo ponto, não se pode em poesia, desfrutar meramente o som e a cor por si mesmo: tem-se de presumir aquilo a que as imagens estejam sendo aplicadas. E o simbolismo pode ser definido como uma tentativa, através de meios cuidadosamente estudados - uma complicada associação de ideias, representada por uma miscelânea de metáforas - de comunicar percepções únicas e pessoais." WILSON, Edmund. O castelo de Axel - estudo sobre a literatura imaginativa de 1870 a 1930 (1931). Trad. José Paulo Paes. 9. ed. São Paulo: Cultrix, 1993, p. 22. 
profanação, que pode ser melhor dimensionada a partir das formulações de David Harlan:

Os atos da fala são eventos localizados em pontos específicos no tempo e em contextos sócio-culturais concretos. Aquele que fala e aquele que ouve estão imediatamente presentes um ao outro, e partilham uma realidade comum à qual os significantes podem se referir e se incrustar instantaneamente. Por estas razões, a referência nos atos da fala não é tida como problemática. [...] fala não é o mesmo que escrita, escritores não são o mesmo que pessoas falando, e leitores não são a mesma coisa que ouvintes; [...] Não há diálogo entre escritor e leitor: o leitor não interroga o escritor, e o escritor não responde ao leitor. Como explicou Paul Ricoeur em Hermeneutics and the Human Sciences, "o leitor está ausente do ato de escrever; o escritor está ausente do ato de ler. $\mathrm{O}$ texto produz portanto um duplo eclipse de leitor e escritor". E se a realidade comum partilhada pelo que fala e pelo ouvinte não pode ser transferida ao escritor e leitor, e significantes não podem portanto ser fundamentados no ato da sugestão, da insinuação (como se dá nos atos da fala), então a referência e a representação tornam-se altamente problemáticas. Uma vez que o texto encontra-se liberado da referência autoral, ele é também liberado da intenção autoral. Dessa maneira o autor se desvanece, suas intenções desaparecem, e o texto começa a oferecer possibilidades que seu autor pode jamais sequer ter imaginado ${ }^{44}$.

Ainda que os historiadores sociais da literatura declarem explicitamente que a historicização que pretendem da obra literária não define preferências quanto aos formatos por ela assumidos, podendo ser indiscriminadamente o conto, a crônica, a poesia e o romance ${ }^{45}$, é forçoso notar que, ao abordar a fabulação romanesca, tenham por objeto privilegiado aquela circunscrita ao século XIX. O recorte temporal já indica a predominância para o romance de traços realísticos, bem como para um

44 HARLAN, David. A história intelectual e o retorno da literatura. Trad. José Antonio Vasconcelos. Campinas-SP: IFCH, Unicamp, 2000, p. 7-8. Mimeo. (Publicação original: Intellectual history and the return of literature. In: The American Historical Review, v. 94, n. 3, jun. 1989).

45 CHALHOUB, Sidney; PEREIRA, Leonardo A. de Miranda. Apresentação. 1998. Op. cit., p. 7. 
corpus textual que é expressão e produto da constituição da noção mesma de autor como proprietário, origem e causa da obra; fruto que é, enquanto identidade autossuficiente, de um movimento de apagamento das dívidas de todo aquele que escreve à própria cultura e da sua condição de leitor ${ }^{46}$. Referimo-nos aqui, explicitamente, àquilo que Verena Alberti indicou como evento significativo e decisivo no século XIX para a definição do que até hoje se entende por literatura, ou seja, a "relação de contigüidade entre 'criador' e "criatura" " ${ }^{47}$. Na mesma direção, pode-se tomar em consideração que a predominância de fabulações romanescas dos oitocentos, como objeto destes historiadores, encontra uma razão na acentuada linearidade que, nas mesmas, organiza a diegese. Cabe ainda acrescentar que o foco incide predominantemente sobre aquelas identificadas com a rubrica de brasileiras, praticamente inexistindo produções de outros lugares.

Em menor escala, podemos observar estudos dirigidos ao literário das primeiras décadas do século XX, cultivador de comunicabilidade com a literatura modernista ou com as vanguardas. Aquela para a qual Barthes aponta como elemento fundante a percepção ou o sentimento de que o texto "se faz e se lê de tal forma que nele, em todos os níveis, ausenta-se a figura do autor"; ausência que "transforma radicalmente o texto moderno"48.

Os estudos voltados para esse período desenvolvem-se em duas direções. A primeira objetiva uma "profanação" dos estudos literários, uma vez que se dedica a explorar como a memória ou a(s) imagem(s) de um autor ou obra foi cunhada ao longo do tempo ${ }^{49}$. De outra parte, quando se trata da ocupação efetiva da literatura, é, em especial, na condição de produções de homens de letras, na sua oposição necessariamente pressuposta às produções dos homens sem letras, que esse literário é observado. Ou seja, é o literário convertido à genérica e imprecisa noção de objeto cultural, cujo

46 ZILBERMAN, Regina. Minha teoria das edições humanas. Memórias póstumas de Brás Cubas e a poética de Machado de Assis. In: ZILBERMAN, Regina et al. As pedras e o arco. 2004. Op. cit., p. 17-117.

47 ALBERTI, Verena. Literatura e autobiografia: a questão do sujeito na narrativa. Estudos Históricos, Rio de Janeiro, v.4, n.7, p. 66-81; 1991, citação p. 66.

48 BARTHES, Roland. A morte do autor (1964), 1988. Op. cit., p. 68.

49 Cf. RODRIGUES, João Paulo C. de Souza. A geração boêmia: vida literária em romances, memórias e biografias. p. 233-263; FIGUEIREDO, Aldrin Moura de. Letras insulares: leituras e formas da história no modernismo brasileiro. p. 301-331; PALAMARTCHUK, Ana Paula. Jorge Amado: um escritor de putas e vagabundos? p. 333-359. Os três textos in: CHALHOUB, Sidney; PEREIRA, Leonardo A. de Miranda (Orgs.). 1998. Op. cit. 
ponto de origem e causa é o universo das letras, a se constituir em corpus investigativo. Trata-se de exercícios que objetivam recolher a postura, opinião, ou juízos dos homens de letras sobre as manifestações da cultura popular, sejam elas musicais, rítmicas, ou relativas às várias formas de sociabilidade - religiosas ou esportivas ${ }^{50}$. Vale a pena notar como em estudo sobre a crescente popularidade atingida pelo futebol no seio das camadas populares no início do século XX, esta configuração do literário se estabelece:

Mais do que incompreensão, o episódio aponta para a desconsideração com a qual esses escritores tratavam da devoção dos grupos iletrados pelo futebol, que seria para eles um mero reflexo das campanhas movidas por suas penas. [...]. Não correspondendo a uma preocupação da lógica que movia aqueles 'marmanjos' que jogavam pelas ruas ${ }^{51}$.

Pode-se ainda notar que o escrutínio do literário aí implicado parece ensejar-se mais como exercício de reparação das produções de homens sem letras, por meio do ato que as quer inscrever neste outro exemplar de cultura letrada - a historiografia:

Pensando seus textos não como espelho da realidade, mas como tentativa de intervenção sobre outros grupos sociais - o que faz com que eles tenham claramente marcado o seu caráter político - podemos nos livrar da tentação de reproduzir, nas análises sobre o período, o mesmo tipo de história que nos é contada por estes homens de letras, desconsiderando a lógica de outros grupos que se entregavam com paixão ao jogo de bola ${ }^{52}$.

Se a orientação aqui é justamente para que se desconsidere o tipo de história que nos é contada por estes homens de letras, em proveito da

50 Cf. PEREIRA, Leonardo A. de Miranda. O jogo dos sentidos: os literatos e a popularização do futebol no Rio de Janeiro. In: CHALHOUB, Sidney; PEREIRA, Leonardo A. de Miranda (Orgs.). 1998. Op. cit., p. 197-231; CUNHA, Maria Clementina Pereira. De Sambas e passarinhos: as claves do tempo nas canções de sinhô. In: CHALHOUB, Sidney; NEVES, Margarida de Souza; PEREIRA, Leonardo A. de Miranda (Orgs.). 2005. Op. cit., p. 547-590.

51 PEREIRA, Leonardo A. de Miranda. O jogo dos sentidos. 1998. Op. cit., p. 197-231. p. 219. Destaque nosso.

52 Ibid., p. 223. 
história experimentada pelos homens sem letras, por outro lado indiciase procedimentos de resgate e recuperação (supostamente a contrapelo das verdades instituídas por dada historiografia de ofício ou história da literatura), de histórias que literatos tramaram sobre o particular ou o local, identificando-o com uma região, a nação, um grupo étnico ou classe social:

Minha perspectiva [...] busca incorporar a produção literária não apenas como fonte para a história - reveladora de informações sobre os contextos sociais de uma determinada época, mas também, e especialmente, como fonte de história, na qual se pode recuperar as diferentes leituras que os autores concebem, através da ficção, a respeito da história do país ${ }^{53}$.

Cabe ainda destacar que para a abordagem da produção circunscrita aos finais do XIX e início do século XX - é a crônica o gênero preferencialmente focalizado. Aquele gênero que comumente se define como mais interessado no real do que no possivivel $^{54}$. Dela pode-se dizer que é, sem dúvida, o gênero mais abordado no conjunto desta produção historiográfica. Mesmo quando obras ficcionais são centrais aos focos de decifração, é à crônica que se recorre para atestar hipóteses e confirmar indícios de operações alegóricas cuja destinação é a História.

53 FIGUEREDO, Aldrin M. Letras insulares. 1998. Op. cit., p. 301.

54 A propósito desta caracterização do gênero crônica, afirma Antonio Candido: "Ora, a crônica está sempre ajudando a estabelecer ou restabelecer a dimensão das coisas e das pessoas.”. CANDIDO, Antonio. A Vida ao Rés-do-Chão. In: A crônica: o gênero, sua fixação e suas transformações no Brasil. Campinas: Ed.Unicamp; Rio de Janeiro: Fundação Casa de Rui Barbosa, 1992, p. 13-22; citação p. 14. Margarida de Souza Neves acrescenta: “A crônica, pela própria etimologia - chronus/crônica - é um gênero colado ao tempo. Se em sua acepção original, aquela da linhagem dos cronistas coloniais, ela pretendese registro ou narração dos fatos e suas circunstâncias em sua ordenação cronológica, tal como estes pretensamente ocorreram de fato, na virada do século XIX para o século XX, sem perder seu caráter de narrativa e registro, incorpora uma qualidade moderna: a do lugar reconhecido à subjetividade do narrador. Num e noutro caso, a crônica guarda sempre de sua origem etimológica a relação profunda com o tempo vivido. De formas diferenciadas, porque diferente é em cada momento a percepção do tempo histórico, a crônica é sempre de alguma maneira o tempo feito texto, sempre e de formas diversas, uma escrita do tempo. Não fosse senão por essa razão, já seria justo que delas se ocupassem os historiadores." NEVES, Margarida de Souza. Uma escrita do tempo: memória, ordem e progresso nas crônicas Cariocas. In: $A$ crônica. O gênero, sua fixação e suas transformações no Brasil. Campinas: Ed. Unicamp; Rio de Janeiro: Fundação Casa de Rui Barbosa, 1992, p. 75-92; citação p. 82. 
Entre os romancistas, sem sombra de dúvidas, Machado de Assis ganha posição privilegiada. Na introdução à já citada coletânea $A$ história contada, ao comentar a presença de trabalhos a ele dedicados afirma-se logo de início: "Machado de Assis é o mote comum aos quatro artigos que abrem o volume. Há nisso quiçá respeito ao cânone, ou há mais que cabe ao leitor descobrir" ${ }^{\prime 5}$.

Talvez esse mais que cabe ao leitor possa ser definido como um mais relacionado ao próprio cânone que estes historiadores dizem respeitar. Um mais que se quer complemento e reiteração ao próprio estabelecimento do cânone enquanto tal. Em outras palavras: um mais para Machado que talvez se queira prolongamento e, principalmente, cumprimento do programa metodológico de "leitura realista da prosa" ${ }^{56}$ de parte da crítica literária brasileira, em especial de seu projeto de alçar Machado à "consciência coincidente com o próprio Brasil" na sua particularidade.

Nesse sentido, vale a pena observarmos duas questões a propósito do empreendimento destes historiadores em relação a Machado. Em primeiro lugar, sua vinculação com uma tradição de estudos de crítica literária sobre o autor de Dom Casmurro, cuja referência mais atual é o nome de John Gledson ${ }^{57}$. Seus trabalhos, por sua vez, relacionam-se a um movimento empreendido nos Estados Unidos, em finais da década de 1960 , contra os excessos formalistas então dominantes na academia norteamericana, ancorado nas formulações de E. D. Hirsch Jr., em Validity in interpretation $(1967)^{58}$. Ou seja, no "intencionismo", como nomeado pelo próprio Gledson, que "procurava estabelecer princípios de interpretação baseados nas intenções do autor, contrapondo-se ao New Criticism, ao desconstrutivismo de Jacques Derrida e ao pós-estruturalismo de Michel Foucault e Roland Barthes" ${ }^{99}$. De outra parte, os estudos de Gledson sobre

55 CHALHOUB, Sidney; PEREIRA, Leonardo A. de Miranda (Org.). Apresentação. 1998. Op. cit., p. 9.

56 SANTIAGO, Silviano. Para além da história social. In: RIEDEL, Dirce Côrtes (Org.) Narrativa: ficção e história. Rio de Janeiro: Imago, 1988, p. 241-256; citação p. 248. Destaque nosso.

57 GLEDSON, John. Machado de Assis: impostura e realismo - uma interpretação de D. Casmurro (1984). São Paulo: Companhia das Letras, 1991; Machado de Assis: ficção e história (1986). 2. ed. revista e ampliada. Rio de Janeiro: Paz e Terra, 2003; Por um novo Machado de Assis: ensaios. São Paulo: Companhia das Letras, 2006.

58 HIRSCH Jr., E. D. Validity in interpretation. New Haven: Yale University Press, 1967.

59 GUIMARÃES, Hélio de Seixas. O Machado terra a terra de John Gledson. Novos Estudos - CEBRAP. São Paulo, n. 77, março de 2007. Disponível em: <http://www.scielo.br/scielo.php?pid=S0101$33002007000100015 \&$ script=sciarttex t\&tlng=en $>$. Acesso em: 11/10/2008. 
Machado são declaradamente tributários das formulações de uma tradição de crítica literária no Brasil, cujo programa metodológico Silviano Santiago nomeou de "leitura realista da prosa" e que tem Antonio Candido como figura de proa. Candido teria admitido a incompletude de suas análises ou de suas demonstrações sobre como o autor de o "Instinto da Nacionalidade" cumpriu o programa romântico de constituir uma obra universal a partir de referências locais ${ }^{60}$. Roberto Schwarz, por seu lado, em Ao vencedor as batatas, ao buscar preencher a lacuna admitida por Candido firma, justamente contra a imagem de um Machado "alienado e indiferente aos processos sociais e históricos brasileiros" ${ }^{\prime \prime 1}$, a imagem daquele que expressou e simbolizou agudamente a estrutura social da sociedade brasileira do século XIX. Na mesma direção, Gledson procurou enfatizar que, muito mais do que expressar a estrutura social - a sociedade patriarcal brasileira do século XIX -, a matéria mesma de que Machado compõe sua ficção são os próprios fios da história local, ou seja, da história brasileira ou da História do Brasil. $\mathrm{Na}$ abordagem do literário denominada história social da literatura, Machado aparece como mais do que aquele que faz da história local a matéria mesma de sua ficção; aparece como aquele que erige como matéria as mudanças ou os movimentos de dissolução da estrutura patriarcal da sociedade brasileira daquele momento. Aos olhos desses historiadores, a narração que Machado empreende dessa dissolução, mais do que simbolizar um sentido para a mesma, é dela coincidente. Sentido que, aliás, diga-se de passagem, não pode ser outro senão aquele cunhado pelos próprios historiadores bem posteriormente ao tempo vivido e experimentado pelo próprio Machado.

Todavia, eis como a perspectiva sobre Machado é enunciada na obra Machado de Assis, historiador:

Os três primeiros capítulos interpretam romances de Machado de Assis, em busca do sentido das mudanças históricas do

60 Conferir a propósito desta questão: FISCHER, Luís Augusto. Para uma descrição da literatura brasileira no século XX. In: VÉSCIO, Luiz Eugênio; SANTOS. Pedro Brum (Orgs.). História e literatura: perspectivas e convergências. Bauru: EDUSC, 1999, p. 97-142, especialmente p. 114; e os escritos do próprio Antonio Candido: Formação da literatura brasileira: momentos decisivos (1836-1880). (1959). 6. ed. Belo Horizonte: Itatiaia, 1981, v. 2, p. 114-115, 220 e 368-369; Esquema de Machado de Assis. In: Vários escritos (1970). 2. ed. São Paulo: Duas Cidades, 1977, p. 13-32.

61 GUIMARÃES, Hélio de Seixas. 2007. Op. cit., p. 2. 
período, segundo a visão dele, e conforme a sua intenção, ou ao arrepio dela.

$[\ldots]$

Não me ocorreria ler as histórias de determinado modo sem o estofo da História que conto depois, mas que não aprendi depois. Também é verdade que não veria História nenhuma nas histórias de Machado de Assis sem a experiência intelectual de ler outros intérpretes dele, com os quais tento estabelecer um diálogo mais direto. Refiro-me, principalmente, a John Gledson e a Roberto Schwarz.

$[\ldots]$

Ao contar suas histórias, Machado de Assis escreveu e reescreveu a história do Brasil do século $\mathrm{XIX}^{62}$.

Sabemos, por outro lado, como a partir dos anos 1970 a crítica literária no Brasil, segundo Benedito Nunes e José Guilherme Merquior, tomou outras formas que não aquela em que a nação se faz critério de validação da cultura e da reflexão:

Benedito Nunes formula assim o problema: "Entre 1960 e 1990, avolumam-se a Historiografia setorial, à conta de diferentes autores e a dos gêneros, a que se juntam Panoramas, antologias e sínteses de caráter ensaístico"; "essa pletora de produção chega junto com a crise teórica da Historiografia literária", diz ainda; mais especificamente: "Em grande parte, a Historiografia literária brasileira das três últimas décadas, por força da historicização dos cânones passados, é ativada pela dinâmica das redescobertas e reavaliações", sendo exemplar disso a revisão de Souzândrade. Merquior também constatara algo parecido: "Ou muito me engano, ou, no universo da crítica paulista, a teorização da literatura e de sua análise ficou mais bem dominada pelas correntes formalistas locais (entre as quais sobreleva o concretismo) do que pela perspectiva históricosociológica advogada e seguida por Candido"63.

62 CHALHOUB, Sidney. Machado de Assis: historiador. São Paulo: Companhia das Letras, 2003 , p. 12,13 e 17.

63 FISCHER, Luís Augusto. Para uma descrição da literatura brasileira no século XX. 1999. Op. cit., p. 97-142; citação p. 102. 
A fim de salientarmos como a preferência por determinados modos de operação com o literário define desdobramentos significativos sobre o modo de pensar a produção cultural brasileira, queremos aqui formular uma questão que nos parece central: se esse quadro por si só não atesta o quanto esta historiografia do literário, ou a história social da literatura, é motivada pelo desejo de retomar o espaço da crítica literária "históricosociológica" no cenário intelectual, buscando ela própria completar ou cumprir o seu programa metodológico de análise de obras literárias, cujo critério de validação se sustenta na idéia de nação e/ou na consciência que com ela deve coincidir?

Uma primeira consideração, quando se trata de refletir sobre o segundo modo como as pesquisas vêm sendo conduzidas - o texto literário como substrato para o escrutínio de percepções, representações, figurações, por meio das quais se buscam os movimentos de instituição de imaginários e da própria temporalidade enquanto tal -, diz respeito à própria noção de fonte e documento e, em especial, do seu alargamento promovido ao longo do século XX e acentuado nas suas últimas décadas. Alargamento que coincidiu com a profissionalização crescente do campo e, entre nós (mas não somente), com o aumento das reflexões a propósito do métier do historiador e da história como lócus de conhecimento e de compreensão do humano.

O ponto nodal destas reflexões concentra-se na natureza da história enquanto narrativa, tramada e tecida a partir dos fragmentos que a documentam, que se querem e são vistas como portadoras de sentido e, para além disso, possuem e devem possuir sentidos plausíveis.

Caindo [...] no espaço público, o livro de história, coroamento do "fazer história", reconduz o seu autor ao cerne do "fazer a história". Arrancado do mundo da ação pelo arquivo, o historiador reinsere-se nele ao inscrever seu texto no mundo de seus leitores; por sua vez, o livro de história faz-se documento, 
aberto à série de reinscrições que submetem o conhecimento histórico ao processo contínuo de revisão ${ }^{64}$.

A reflexão de Ricoeur permite inserir na mesma cadeia de compreensão e narrativa do mundo as diferentes escrituras que podem dele dizer, em seus diferentes modos de narratividade. Apresenta a história como "uma escrita, de uma ponta a outra: dos arquivos aos textos de historiadores, escritos, publicados, dados a ler" 65 e a narratividade como elemento constitutivo tanto dos documentos adormecidos nos arquivos como dos textos dos historiadores, entre outros.

A utilização de fontes caracterizadas como literárias ou portadoras de literariedade ocorre portanto, neste caso, por formas múltiplas; pela própria abertura, também múltipla, aos significados que possam vir a ser operados e buscados nas relações entre textos nos seus mais diversos gêneros - desde a literatura de viagens, aos romances, crônicas, poemas, ensaios... que possam, cada qual com suas características específicas, ao dizer do passado no presente e projetar futuros, a temporalidade portanto, constituir apoio para o que denominamos conhecimento histórico. Conhecimento concebido e reconhecido como caracterizado pela lacuna e fragmentariedade - a dos documentos que informam o historiador e, por consequência, da narrativa historiadora - que resulta na atribuição de sentido, ou sentidos, sempre conferidos por aquele que exerce o seu ofício. Em "A áspera verdade - Um desafio de Stendhal aos historiadores", Ginzburg sublinha a afirmação de Auerbach de que "através de um acontecimento acidental, uma vida qualquer, um trecho tomado ao acaso, se possa chegar a uma compreensão mais profunda do todo" "66, manifestada, Ginzburg supõe, sob inspiração de Marcel Proust e Virginia Woolf ${ }^{67}$. Considerações que afinam com os

64 RICOEUR, Paul. A memória, a história, o esquecimento (2000). Trad. Alain François et al. Campinas: Ed.Unicamp, 2007. Em especial o Item I. Representação e narração (Parte II - História/ Epistemologia // 3. A Representação Historiadora), p. 250-260; (itálico no original). Ver também VEYNE, Paul. Como se escreve a História (1971); Foucault revoluciona a História (1978). Trad. Alda Baltar e Maria Auxiliadora Kneipp. 2. ed. Brasília: Ed. UnB, 1992.

65 RICOEUR, Paul. A memória, a história, o esquecimento (2000). 2007. Op. cit., p. 247 (itálico no original).

66 AUERBACH, Eric. Apud GINZBURG, Carlo. A áspera verdade (2006). 2007. Op. cit., p. 173. Ginzburg considera que a afirmação constitui ideia "totalmente estranha às histórias da literatura tradicionais".

67 Ibid., p. 172. 
desenvolvimentos que ele mesmo perseguiu na perspectiva da micro-história e que nos ajudam a confirmar as múltiplas e, talvez, infindas possibilidades da história em lidar com os mais diferentes registros/escrituras para a construção de suas narrativas. O historiador aparece e adquire consistência, portanto, como sujeito de conhecimento que recolhe e organiza os indícios e escritos, entre eles os literários, para a figuração e dotação de sentido ao passado $^{68}$. Escritos que, por sua vez, também foram elaborados a partir de escolhas, mais ou menos deliberadas, de seus autores.

Colaboram, ainda, para a aproximação à perspectiva que buscamos explorar, suas constatações a propósito das análises contidas em Mimesis. Ginzburg anota que muitos "leitores dão por líquido e certo que todos os textos discutidos por Auerbach são, em maior ou menor grau, textos de ficção", quando na verdade, há uma alternância de poetas, romancistas e historiadores, ou seja, uma coexistência que hoje "pode parecer pacífica" 69 . Como sabemos, nem sempre foi assim.

Peter Gay, na conclusão a $O$ estilo na História, afirma que, da perspectiva dos historiadores que analisou - Gibbon, Ranke, Macaulay, Burckhardt -, que estende para a perspectiva da "profissão histórica moderna em geral, a arte e a ciência não se separam nitidamente; condividem uma longa fronteira cheia de meandros, que é atravessada pelo trânsito erudito e literário sem grandes impedimentos e muitas formalidades" ${ }^{" 70}$.

Há ainda, neste modo de proceder com o literário, a consideração de que "nada do que ficou arquivado do passado o foi inocentemente", como lembra Albuquerque Jr. com base em Mal de arquivo, de Derrida. O arquivo aparecendo como "fruto de operações políticas e de sentido", de que deduz serem os procedimentos "teóricos e metodológicos" aqueles que evidenciam e dotam de significado os documentos, ou os relegam ao esquecimento ou adormecimento, sem que saibamos por quanto tempo

68 A propósito ver RICOEUR, Paul. A memória, a história, o esquecimento (2000). 2007. Op. cit., em especial a parte II - História/Epistemologia.

69 GINZBURG, Carlo. A áspera verdade (2006). 2007. Op. cit., p. 170-171. O autor afirma que essa interpretação corrente, que "teria horrorizado Auerbach", contribuiu para a "fama duradoura [de Mimesis] nas universidades americanas".

70 GAY, Peter. O estilo na História. Gibbon, Ranke, Macaulay, Burckhardt (1974). Trad. Denise Bottmann. São Paulo: Companhia das Letras, 1990, p. 167.

71 ALBUQUERQUE Jr., Durval Muniz de. Introdução. 2007. Op. cit., p. 19-39. Para as citações, p. 25-26 
mais. A ideia é a de que evidência e história não existem ou não se evidenciam por si mesmas, mas aguardam quem as construa e as enforme.

A propósito, Roudinesco nos lembra, de forma bastante esclarecedora, a importância do arquivo como condição da história, enfatizando que tanto a obediência cega à sua positividade e poder absoluto, quanto a sua recusa levam à sua impossibilidade; o seu "culto excessivo" resultaria "numa contabilidade (a história quantitativa) destituída de imaginação" e, proibindo "que possamos pensar a história como uma construção capaz de suprir a ausência de vestígios" 72 .

Num olhar que consideramos preliminar, encontramos alguns direcionamentos que, de forma mais ou menos incisiva, percorrem o escrutínio do literário nesta perspectiva, que inicia por considerá-la, a literatura, como uma entre as inúmeras fontes de que o historiador dispõe para aproximar-se de um tema e/ou um período histórico. Prática não enunciada, uma vez que o que talvez se pudesse considerar como declaração de intenções, se encontre diluído nas considerações sobre a importância do alcance dos textos literários na sua qualidade de dizer, não somente ao intelecto como aos sentidos, ou mesmo na tessitura das suas relações com a política, acentuando, mais uma vez, o seu poder de convencimento, não somente pela razão, como pela sensibilidade, imaginação e, mesmo, pelas paixões.

Em artigo recente, Stella Bresciani, ao constatar historicamente a "presença constante de textos literários utilizados como documentos" nos estudos sobre cidades e urbanismo, verificou a sua utilização "sem a necessária mediação". No caso, a literatura aparece como "retrato de época da sociedade; um espelho, ainda que ao dar ênfase especial a determinados aspectos da 'realidade' social lhe impusesse certa deformação". Como se houvesse a possibilidade de alcançar "uma imagem verdadeira ou a reapresentação verídica das principais questões do século XIX, no decorrer do qual a cidade se tornou um problema exigindo a intervenção do saber especializado". Bresciani observa, ainda, que o "autor de ficções também se subordinou, e ainda o faz, aos cânones de sua especialidade" ${ }^{\text {?3 }}$, como

72 ROUDINESCO, Elisabeth. A análise e o arquivo (2001). Trad. André Telles. Rio de Janeiro: Jorge Zahar, 2006. p. 9.

73 BRESCIANI, Stella. Literatura e cidade. In: CARDOSO, Selma Passos; PINHEIRO, Eloísa Petti; CORRÊA, Elyane Lins (Orgs.). Arte e cidades. Imagens, discursos e representações. Salvador: Ed. UFBA, 2008, p. 9-40; citações p. 30. 
lugar de autor em que nos colocamos ao redigirmos nossos textos que também se subordinam a um campo conceitual nem sempre explicitado. Ou seja, se toda linguagem é válida como documento, cada linguagem precisa ser analisada a partir de seu próprio campo "disciplinar" e condições de produção ${ }^{74}$.

Uma outra preocupação perceptível - não explicitada - é a inexistência de privilegiamento de um recorte temporal ou espacial específico na escolha ou definição das temáticas a serem aprofundadas. Não há preocupação com a atribuição às variadas escritas/escrituras de valores explicativos de um real já dado ou de uma história pré-existente às fabulações romanescas/literárias a que as mesmas necessariamente fariam referência, simbolizariam, esclareceriam e/ou eventualmente explicariam; busca-se nelas, ao contrário, a variabilidade mesma, que considera e procura contemplar os diferentes modos de instituição de imaginários e suas construções, seja do presente ou do passado. Não se procura atribuir, também, maior ou menor capacidade de vinculação com o vivido a um ou outro gênero de produção literária em suas diferentes historicidades.

Pontos importantes, sem dúvida, constituem as formas de aproximação das fontes, que têm por objetivo elucidar como as obras se destinam a um tempo, observando-se que, ao invés da "decifração", a ação objetivada é a do "deslindamento" "75, ou seja, a exploração das múltiplas perspectivas que podem se abrir ao historiador pelos escritos literários que, invariavelmente, os colocam em relação a outros discursos (literários ou não) que lhe são contemporâneos ou que se atualizam no próprio ato de escritura, tornando-se deles contemporâneos. Ao se compreender a obra enquanto escritura e esta enquanto múltiplos polos da cultura, a inquirição se define como averiguação das muitas alteridades que nelas se podem presentificar. Aquilo que, em extremo, na abordagem de Barthes sobre o literário, levaria à consideração de que o texto não é

feito de uma linha de palavras a produzir um sentido único, de certa maneira teológico (que seria a "mensagem" do

74 Ibid., p. 34.

75 "Na escritura múltipla, com efeito, tudo está para ser deslindado, mas nada para ser decifrado [...]". BARTHES, Roland. A morte do autor (1968), 1988. Op. cit., p. 69. 
Autor-Deus), mas um espaço de dimensões múltiplas onde se casam e se contestam escrituras variadas, das quais nenhuma é original: o texto é um tecido de citações, saídas dos mil focos da cultura ${ }^{76}$.

Ou, adentrando diretamente o território do historiador, consideremos as reflexões de Peter Gay a propósito do "longo debate sobre a definição de história"77:

Ele [o historiador] almeja contar histórias reais, mas existem tantas maneiras de contar a mesma história que o próprio sentido de "a mesma" corre perigo. As estratégias expositivas do historiador são todas elas, conscientemente ou não, estratégias de persuasão. Assim, o estilo, justamente por ser a marca que diferencia e distingue o historiador, é também a prova de sua invencível subjetividade ${ }^{78}$.

Não se procura exemplificar ou ilustrar a história, percurso considerado já conhecido por outros meios, pela utilização do texto literário. A obra literária é perscrutada pelo olhar do historiador que, de seu presente, propõe e escolhe caminhos a serem percorridos, buscando possibilidades nessa incessante relação de construção do passado. A literatura é, nesse sentido, tomada como "lugar de boas perguntas acerca de um problema, como lugar de fecundação do pensamento" e não como "manancial de informações a serem extraídas pelo historiador meticuloso"79.

Nesse sentido múltiplo ou podendo conter múltiplos focos, procurase dirigir o olhar (ou olhares), não para profundidades e origens que possam estar contidas nas obras literárias, mas para as dispersões que as constituem; e, considera-se ainda que, conquanto as obras literárias contenham, elas mesmas, imagens e figurações, não deixam de solicitar do historiador um esforço de captação - de deslindamento e estabelecimento de relações - dos múltiplos focos que as compõem, não como algo que se destina

76 Ibid., p. 68-69.

77 GAY, Peter. O estilo na História (1974). 1990. Op. cit., p. 167.

78 Ibid., p. 177.

79 GUIMARÃES, Manoel Luiz Salgado. Prefácio. In: ALBUQUERQUE JR., Durval Muniz de. História: a arte de inventar o passado. 2007. Op. cit., p. 15-18; citação p. 17. 
somente a um tempo, espaço, ou a uma anterioridade concretamente dados (a História), mas enquanto algo que se destina a um externo vislumbrado, traçado, inscrito e, por que não, imaginado em si mesmas, ou seja, nas próprias obras literárias.

As reflexões de Ítalo Tronca, que partem do conto "A terceira margem do rio", de Guimarães Rosa, e dos estudos de Foucault sobre a loucura, nos ajudam a bem formular a questão:

Na História da Loucura, principalmente o capítulo intitulado Stultifera Navis, Foucault indica implicitamente como a genealogia de uma temática pode ser esteticamente representada na obra de arte; a obra relataria, plástica ou literariamente, aquilo que os documentos apontariam como fato histórico, permitindo ao pensador de um outro tempo detectar as dinâmicas próprias das representações no tempo. O documento e a arte forneceriam instrumentos para, em um outro tempo e em um outro espaço, compreendermos como o imaginário vai se tornando, paulatinamente, objeto de reflexão e, nessa trajetória, vai perdendo sua identidade primeira ${ }^{80}$.

Questionamento que problematiza as intrincadas relações da história com o texto literário, extravasando para aquelas entre memória e história, ou entre história e história da literatura que contribuem, nos parece que ambas, para a cristalização de marcos de memória construída que podem colaborar para a naturalização de certas interpretações do passado, forma esta, como sabemos, tributária dos procedimentos positivistas novecentistas, de maneira a lhes conferir caráter mítico, além de definir os cânones do que compõem e de que forma compõem a história da literatura nacional/ brasileira (se retomamos o nosso recorte-Brasil), que informa ou enforma a sua história.

$\mathrm{Na}$ aproximação entre o literário e o político, adquire centralidade, mais uma vez, a ideia de formação, em especial se pensamos na produção literária e historiográfica sobre o Brasil dos séculos XIX e XX. Desde o início do século XIX repercutem os vínculos entre literatura e história, ou

80 TRONCA, Ítalo. História, razão e loucura: A terceira margem... In: NAXARA, Márcia; MARSON, Izabel; BREPOHL, Marion (Orgs.). Figurações do outro. Uberlândia: Edufu, 2008. 
melhor, das histórias literárias transfiguradas em histórias da nação, além dos inúmeros projetos de construção da nação e de suas perspectivas futuras que levam em conta as leituras de sua história. Ideia de matriz romântica, pela qual a nação se faz em grande parte por suas letras - concepção que atravessa, também, o século XX. Concepção de que resultaram propostas estético-políticas que pensavam a construção do país - Brasil - por suas letras, natureza e artes e, mais tarde, pela re-descoberta do mesmo ou de um outro Brasil, também pelas mesmas/outras letras, natureza e artes, que fossem capazes de dizer da nação, de dar-lhe uma visibilidade consciente e moderna, inserindo-o, como sempre "sonhado", na senda do progresso e da civilização. Mas não somente isso, tratava-se de redescobrir a nação e seu sentido, pautado na inspiração da cultura popular.

Esses literatos-folcloristas acreditavam na existência de "realidade histórica e cultural" concretas, durante as décadas de 1920 e 1930, capazes de impulsionar uma cruzada em prol de um "segundo descobrimento do Brasil", definido por uma conjuntura histórica específica, em que o artista culto (intelectual), inspirado na cultura popular, poderia escrever uma obra autônoma como uma metáfora de toda a nação ou do povo brasileiro $^{81}$.

Quando se pensa, no entanto, os marcos de modernidade para o Brasil, não há consenso. Pode-se retomar o programa modernista e a re-leitura de Brasil realizada a partir desse movimento e da demarcação do romantismo e do modernismo como marcos de tomada de consciência e consolidação da nação ${ }^{82}$ que ganha concretude no movimento de redescoberta proposto pelos intelectuais vinculados ao movimento de 1922, com sequência nos anos 1930.

81 CONTIER, Arnaldo D. Modernismos e brasilidade. Música, utopia e tradição. In: NOVAES, Adauto. Tempo e história. São Paulo: Companhia das Letras; Secretaria Municipal da Cultura, 1992. p. 259-287; citação p. 273.

82 CANDIDO, Antonio. Literatura e sociedade: estudos de teoria e história literária (1965). 7. ed. São Paulo: Nacional, 1985. "Na literatura brasileira, há dois momentos decisivos que mudam os rumos e vitalizam toda a inteligência: o Romantismo, no século XIX (1836-1870) e o ainda chamado Modernismo, no presente século (1922-1945). Ambos representam fases culminantes de particularismo literário na dialética do local e do cosmopolita; ambos se inspiram, não obstante, no exemplo europeu." (p. 112. Destaque nosso). 
Há, neste dissenso, para além das demarcações cronológicas, a centralidade mesma do que sejam modernismo e modernidade no que conhecemos como cultura ocidental - entre nós, mas não somente. Dissenso que se faz acompanhar, também, da discordância quanto a marcos excessivamente definidos, capazes de rotular o que veio antes como "pré" (a que se atribui um sentido de falta), de maneira a, com isso, reduzir o sentido mesmo da modernidade para se pensar o Brasil e seus movimentos, não somente culturais, mas abrangentes, de forma a comportar também os demais signos de progresso e modernidade, vinculados ao desenvolvimento técnicocientífico, em sintonia com o mundo ocidental - claramente perceptível nos diversos projetos para um Brasil futuro, presente nos ensaios literários e nas iniciativas vinculadas à ocupação das terras interiores - nossos inúmeros sertões - por meio do engenho e arte da moderna tecnologia (telégrafo, ferrovia, navegação a vapor $)^{83}$, que possibilitariam reavaliar, na afirmação de Hardman, as balizas dos anos 1920/1930, ao menos para a segunda metade do século XIX ${ }^{84}$, uma vez que,

\begin{abstract}
Assim como os sentidos de modernidade e modernização têm sido, com bastante freqüência, reduzidos a esquemas ideológicos desenvolvimentistas do Estado brasileiro pós1930, os sentidos de modernismo, como tendência geral, foram também homogeneizados a partir de valores, temas e linguagens do grupo de intelectuais e artistas que fizeram a Semana de Arte Moderna, em São Paulo, no ano de $1922^{85}$.
\end{abstract}

Ganham importância aí, a participação do Brasil, em sintonia e o pioneirismo das experiências internacionais com as "artes mecânicas da fotografia e, mais tarde, nos primeiros ensaios do cinematógrafo" 86 .

83 NAXARA, Márcia R. C. Ciência, técnica e história no século XIX. Fragmentos e perspectivas de Brasil. Apresentado no Seminário A dinâmica do Historicismo: tradições historiográficas modernas (DEHIS-UFOP - 19-21 ago. 2008) a ser publicado pela Editora Argvmentvm (Belo Horizonte), com organização de Sérgio Ricardo da Mata, Flávia Varella e Helena Miranda Mollo. (No prelo).

84 HARDMAN, Francisco Foot. Trem fantasma. A ferrovia Madeira-Mamoré e a modernidade na selva (1988). 2. ed. revista e ampliada. São Paulo: Companhia das Letras, 2005. Em especial o Cap. 7. Os negativos da história. A ferrovia-fantasma e o fotógrafo-cronista.

85 HARDMAN, Francisco Foot. Antigos modernistas. In: NOVAES, Adauto. Tempo e história. 1992. Op. cit., p. 289-305; citação p. 290.

86 HARDMAN, Francisco Foot. Trem fantasma (1988). 2005. Op. cit., p. 221. 
Neste sentido, importa realçar a instigante questão colocada recentemente por Daniel Faria em $O$ mito modernista: pode a história da literatura brasileira (e, acrescentamos nós, a história) ser contada sem a cronologia 1922-1930? Pelo que veio antes e pelo que veio depois? Pelo que entrecruzou e tangenciou esta periodização? ${ }^{87}$ Supomos que sim.

\section{IV}

Se retomamos o nosso ponto de partida com relação à produção historiográfica desenvolvida no Brasil, não é difícil constatar o quanto história e literatura estiveram e são aproximadas para se pensar as nações e nacionalidades (entre elas o Brasil) quando se trata de avaliar a sua importância para contar e cantar a nação - seja pela demarcação e atribuição de valor e significado aos acontecimentos, seja pela procura de compreensão das relações estabelecidas no conjunto da sociedade. Os sentimentos de pertencimento, considerados importantes para dizer da nação e de sua formação, foram objeto de interesse, tendo em vista a busca de signos identitários. Suas nomenclaturas - História do Brasil e Literatura brasileira, no caso - também as vinculam, fortemente, aos espaços e significações nacionais, verdadeiros rótulos, ao que parece necessários, tendo em vista a diversidade e variabilidade das línguas através das quais as múltiplas literaturas ganham existência, conferindo força à demarcação do recorte nacional.

No entanto, não nos parece que tal recorte deva constituir aprisionamento da análise realizada a posteriori pelo historiador. Se literatura e história contribuem para a formação da nação - ou melhor, para a construção de seus símbolos -, a nação não ganha existência somente a partir delas, ou seja, não nos parece adequado que a produção literária sobre o Brasil seja lida privilegiadamente na chave de formação da nação ou de uma crescente consciência da nação sobre si mesma. Via de regra, identidades inventadas e literária brasileira. Revista Brasileira de Literatura Comparada. Rio de Janeiro, n. 9, 2006, p. 13-33. 
construídas a partir do recorte nacional oprimem e/ou escondem as diferentes formulações identitárias que pulsam em seu interior e fronteiras.

Finalmente, reiteramos a constatação de número significativo de estudos que, de forma bastante diferenciada, vêm utilizando a literatura ou dando atenção à literariedade dos textos. Os programas de pós-graduação e linhas de pesquisa frequentemente têm adotado em suas denominações variadas formas que combinam as palavras sociedade, política e cultura que, simultaneamente, apontam e escondem os caminhos tomados pelas pesquisas - a rubrica história social ganha, desta forma, enorme amplitude, não sem perda de muitos de seus significados. Para além dos programas e suas linhas de pesquisa, os grupos interinstitucionais - alguns bastante consolidados - podem colaborar para o deslindamento dos modos de aproximação entre história e literatura, bem como para a utilização da literatura como fonte de pesquisa. Boa parte dos resultados vem sendo, crescentemente, publicada (livros, coletâneas, periódicos), permitindo constatar não somente a dispersão geográfica pelo país, como os contatos dos diversos centros entre si e com pesquisadores de outros países.

Este ensaio resulta de preocupações com o fazer historiográfico recente com um foco bastante específico (que talvez possa ser estendido, com os devidos cuidados, para outras fontes, em especial no campo das artes de forma compreensiva), que consideramos de grande importância e ainda por deslindar em seus meandros e riqueza. Retomamos, neste sentido, a afirmação de Auerbach, de que não lidamos com leis, "mas com tendências e correntes que se entrecruzam e complementam" $" 88$ de forma variada. 